\title{
ENTRE ARIEL E CALIBÃ: RICHARD MORSE E A DEFINIÇÃO DO "OBJETO AMÉRICA LATINA"
}

\author{
BETWEEN ARIEL AND CALIBAN: RICHARD MORSE AND THE DEFINITION \\ OF THE "OBJECT LATIN AMERICA"
}

\author{
Rodrigo Medina Zagni ${ }^{(*)}$ \\ Universidade Federal de São Paulo, Osasco (SP), Brasil
}

Resumo: Richard Morse, um dos mais importantes estudiosos norte-americanos da História do Brasil, teve na obra $O$ Espelho de Próspero sua mais importante e polêmica argumentação já publicada e cujos interlocutores foram, essencialmente, historiadores brasileiros. Nosso objetivo, é o de mapear, por meio de revisão bibliográfica, a discussão historiográfica que se deu a partir do impacto da publicação da obra no Brasil, revelando distintas e significativas visões sobre as relações entre a América Latina e os Estados Unidos, e entre ambos e a Europa; contribuindo assim com este denso e complexo campo de estudos.

Palavras-chave: Richard Morse; Ibero-América; Anglo-América.

Abstract: Richard Morse, a leading American scholars of the Brazilian History, had in his most important work The Prospero's Mirror his controversial arguments already published and whose partners were essentially to Brazilian historians. Our goal is to map, through a literature review, the historiographical discussion that took place from the publication of the piece in Brazil, revealing distinct and significant views about the relations between Latin America and the United States, and between both and Europe. The aim of our is contributing with this dense and complex field of studies.

Keywords: Richard Morse; Latin America; Anglo American.

$(*)$ Doutor, professor do curso de Relações Internacionais da Universidade Federal de São Paulo. E-mail: <rodrigo.medina. unifesp@gmail.com>. Recebido em: 22.08.2014; aceito em: 11.04.2015. 


\section{INTRODUÇÃO}

Richard McGee Morse (1922-2001), historiador e ex-professor de História das universidades de Yale e Stanford, defendeu doutorado no final da década de 1940 sobre a cidade de São Paulo com a tese Formação Histórica de São Paulo, sendo reconhecido hoje como um dos mais importantes estudiosos norte-americanos da História do Brasil.

A obra que assim o consagrou foi $O$ Espelho de Próspero, publicada primeiro no México, em 1982, e no Brasil, em 1988, cujos argumentos ali sugeridos provocaram imensa polêmica no ambiente acadêmico e intelectual brasileiro, sobretudo entre os estudiosos do período colonial. Isso porque, ao invés de condenar a herança ibérica, seguindo a interpretação vigente no período, Morse identificou vantagens que teria a cultura hispânica, em sua flexibilidade e possibilidades de interação com a intransigente cultura norte-americana.

Sua análise teve como meta chegar às "mentalidades" vigentes nas sociedades americanas, partindo da literatura como meio de interpretar a América e relacionando-as a universos distintos no Velho Mundo, que explicariam as profundas cisões que cortam as sociedades do Hemisfério Ocidental. Tendo optado pelo gênero ensaio, a obra é uma espécie de continuação de dois artigos anteriores que exploraram a tradição política latino-americana: Toward a theory of Spanish American Government, publicado no Journal of the History of Ideas (1954); e The Heritage of Latin America, publicado no livro organizado por Louis Hartz (1919-1986), The founding of new societies (1964).

A alegoria do Espelho de Próspero é de origem shakespeareana e faz menção ao universo representado no romance $A$ Tempestade, considerada a última peça de William Shakespeare (1564-1616), escrita de 1610 a 1613. A relação entre o romance e as questões de identidade superestrutural latino-americanas já havia sido feita por diversos autores, o mais célebre deles o ensaísta uruguaio Jose Enrique Rodó (1872-1917), no clássico Ariel (1947), publicado em 1900. Apesar da referência a Ariel, a inspiração para o título, segundo o próprio Morse, foi o ensaio El mirador de Prospero também de Rodó, este já de 1909 e no qual, ao contrário do que possa parecer, o termo mirador se refere à torre, não a espelho.

Seu objeto no ensaio foram as faces anglo-saxônica e ibérica do Novo Mundo, portadoras, no longo processo de interpretações que sofreu, de duas aparências: uma Anglo-América mais moderna e realizada; contraposta à Ibero-América irregular e relativamente atrasada. O objetivo foi o de ampliar as reflexões anteriores e verificar, pelo confronto dialético entre Anglo e Ibero-América, se a civilização ibero-americana, portadora de história, teria alguma mensagem para o mundo moderno.

Para isso, a análise de Morse recorreu ao passado medieval com o objetivo de rastrear o nascedouro das clivagens entre o mundo anglo-saxônico e o ibérico no campo das mentalidades, das concepções de sociedade e das escolhas políticas engendradas por duas realidades: uma cientificista e outra tomista.

No percurso do Ocidente medieval à Europa Moderna, Morse articulou no tempo e no espaço o estudo de autores da Filosofia, Teologia, História, poesia e ensaios literários, 
correntes teóricas, eventos episódicos e processos históricos, construindo um objeto para o qual deu uma ampla visão de conjunto, o que lhe possibilitou identificar pontos de transição, convergências e divergências entre projetos civilizacionais e processos históricos.

No Espelho de Próspero, Anglo e Ibero-América substituíram conceitualmente os termos EUA e América Latina não por mera terminologia, mas para realçar as heranças ideológicas e institucionais recebidas do Velho Mundo pelo Novo Mundo, do que trata, em essência, o ensaio. Os novos conceitos provêm exatamente do estudo do longo processo que teria amalgamado mentalidades distintas e que, por sua vez, teriam resultado em dois modelos de civilização, de escolha política, institucional e social, transportados para o Novo Mundo pela via da colonização.

Para Morse, a tradição latina havia, até ali, sido objeto de profunda mitificação e, por conta disso, a própria origem do termo América Latina estaria carregada de artificialismos, dada a sua construção responder à necessidade de legitimação do avanço de Carlos Luís Napoleão Bonaparte (1808-1873) - Napoleão III de França - em direção ao Hemisfério Ocidental. Na realidade, a tradição latina seria muito mais ampla e antiga, não apenas francesa, mas também italiana e ibérica, o que essa simples construção semântica não compreenderia. Anglo-América e Ibero-America, portanto, são analisadas por contraste numa relação dialética na qual são postas em confronto duas visões de mundo equidistantes.

O ensaio, publicado no Brasil, recebeu variadas leituras, interpretações e foi o epicentro de acalouradas discussões com as quais o próprio autor, em graus distintos, acabou se envolvendo na defesa de suas concepções e tentando dar conta dos comentários entre historiadores no final daqueles anos de 1980 a propósito do livro(1) de que: "o Brasil vai mal, exceto para Morse" ("Uma entrevista com Richard Morse", 1989, p. 82).

É dessas interpretações que trataremos, por meio de um exercício de revisão bibliográfica, nesse breve estudo, buscando sublinhar o posicionamento de parte significativa da historiografia brasileira que se debruçou sobre questões relativas às heranças coloniais no novo mundo, bem como ao contraste entre América do Norte e América do Sul.

Para tanto, dividimos nossa análise em sete partes: a primeira destinada a aspectos de natureza biográfica e ao momento de descoberta, do então jovem Richard Morse, de sociedades latino-americanas, bem como da influência que sua intelectualidade exerceu em seu período formativo; em seguida, verificaremos de que forma Morse teria identificado no passado medieval europeu as escolhas políticas que, por sua vez, determinaram a existência de dois mundos distintos, no Hemisfério Ocidental, depois do séc. XV; noutra sessão, nos dedicaremos às repercussões que o iluminismo, o liberalismo e o marxismo, movimentos europeus, tiveram para essas realidades tão duais no Novo Mundo; logo, em seguida, analisaremos os argumentos de Morse acerca do "desígnio ocidental", espaço de crítica às estereotipadas categorizações já feitas da América Latina por parte

(1) A mais polêmica discussão se deu por meio dos artigos do sociólogo Simon Schwartzman e das respostas de Morse, publicadas na revista Novos Estudos CEBRAP, nos números 22, de outubro de 1988; 24, de julho de 1989; e 25, também de 1989. 
do pensamento intelectual americanista, sobretudo nos EUA; também de uma análise de enquadramento ontológico e axiológico do "Espelho de Próspero", lugar de identificação não de uma filosofia da história a partir de seus elementos teórico-conceituais, mas de uma sociologia da história que teria recorrido, a fim de destacar os EUA do fundo reluzente da América Latina, ao ideal tipo de origem weberiana.

Recuperando discussões historiográficas em torno de suas proposituras, poremos sob análise crítica o conceito de Íbero-América, dado o problema da indistinção, nessa propositura, entre os casos ibérico e lusófono; e, antes de nossas considerações finais e ainda recorrendo ao mapeamento de parte significativa das discussões historiográficas provocadas pelos argumentos de Morse, trataremos do problema da validade da utilização do "jogo de espelhos" - ou seja, da análise por contraste entre EUA e América Latina - para a análise da realidade latino-americana.

\section{A DESCOBERTA DA AMÉRICA POR UM NORTE-AMERICANO}

Informa-nos o próprio Richard Morse ("Uma entrevista com Richard Morse", 1989, p. 77-78) que sua primeira vinda ao Brasil, da qual resultaram suas primeiras impressões sobre o contraste entre a realidade na qual vivia e a realidade ao sul da linha do Equador, não tinha uma finalidade acadêmica. Havia concluído já sua graduação pela Universidade de Princeton, retornado da guerra e iniciado sua pós-graduação na Universidade de Columbia. Desde o primeiro contato com a "Chicago da América do Sul" (como se referia a São Paulo), quis escrever um livro sobre as impressões que o profundo contraste lhe gritara e não uma tese acadêmica.

Contudo, em 1947, ano em que retornou ao Brasil depois de ser contemplado com uma bolsa de estudos, suas obrigações eram essencialmente acadêmicas e o resultado, segundo o sociólogo Antonio Cândido de Mello e Souza (1992, p. 07), foi “... talvez a melhor monografia até hoje escrita sobre a cidade". Durante todo um ano, permaneceu em São Paulo, um mês no Rio de Janeiro e dividindo mais um mês para as capitais dos Estados do Rio Grande do Sul, de Minas Gerais e da Bahia.

Dentre suas indas e vindas ao Brasil, teve intenso contato com uma produtiva e significativa intelectualidade brasileira que sob vários aspectos muito lhe influenciou.

Na Faculdade de Filosofia, na Praça da República, em São Paulo, teve contato direto com os assistentes do professor, ensaísta e sociólogo Fernando de Azevedo (1894-1974): Antonio Cândido e Florestan Fernandes (1920-1995), ambos que se consagrariam, posteriormente, dentre os mais importantes e influentes intelectuais brasileiros e dos quais se tornou não tão somente amigo, mas discípulo, especialmente de Antonio Cândido, "... o crítico literário mais brilhante e promissor do Brasil" (Uma entrevista com Richard Morse”, 1989, p. 77-78), cujas interpretações litarárias e sociológicas develavam um universo de possibilidades de se compreender aspectos significativos das sociedades por meio de sua produção literária, levando ao que, posteriormente, seria chamado de "mentalidades". Conheceu o historiador e crítico literário Sérgio Buarque de Holanda (1902-1982) quando este era diretor do Museu Paulista (entre os anos de 1946 e 1956) e que teria também lhe ajudado enormemente em seus estudos. 
Apesar de não ter conhecido pessoalmente o historiador Caio Prado Júnior (19071990), tomou contato com sua obra e, com isso, com uma interpretação marxista sobre a História do Brasil e da América Latina e que acabou matizando boa parte das interpretações subsequentes sobre o passado colonial.

No Rio de Janeiro, encontrou-se mais de uma vez com o sociólogo e antropólogo Gilberto de Mello Freyre (1900-1987), notadamente o criador de um dos mais difundidos matizes teórico-interpretativos sobre a sociedade brasileira colonial e, mais amplamente, sobre a América Latina.

Também participou de outros círculos intelectuais que compuseram o repertório de influências ao qual esteve circunscrito, neste sentido, em torno dos artistas modernistas que lhe foram apresentados pelo poeta Oswald de Andrade Filho (1890-1954). Dentre eles, os pintores Anita Catarina Malfatti (1889-1964), Lasar Segal (1891-1957) - também escultor - e Emiliano Augusto Cavalcanti de Albuquerque e Melo (1897-1976). No Rio de Janeiro, se encontrou com Manuel Carneiro de Sousa Bandeira Filho (1886-1968), poeta, crítico literário e de arte, representante também do modernismo brasileiro, que constituiu o repertório cultural intensamente produtivo com o qual Morse teve contato e que lhe apresentou, junto de outros modernistas, uma cultura viva que redescobria e reinventava a si mesma.

Essa reinvenção, nas letras e nas artes visuais, tinha importantes representantes nas vanguardas artísticas e intelectuais próximas de Morse; primordialmente, no círculo de São Paulo - a Faculdade de Filosofia, a casa de Oswald de Andrade, a Associação Brasileira de Escritores etc. -, com os quais manteve relações mais intensas.

Não só Oswald, como seu irmão Mário Raul de Morais de Andrade (1893-1945), seriam privilegiados motivos de densas reflexões sobre cultura e mentalidades na sociedade paulista, como no confronto cruzado entre ambos e as obras de Thomas Stearns Elliot (1888-1965) e William Carlos Williams (1883-1963), elaborado por Morse.

Depois da década de 1970, como consultor da Fundação Ford no Brasil, numa passagem muito breve, estreitou seus laços com a comunidade acadêmica carioca, bem como se aproximou do CPDOC da Fundação Getúlio Vargas, criado em 1973 e que publicaria uma série de artigos relacionados à polêmica em torno de suas teses na revista Estudos Históricos.

Em 1992, quando completou 70 anos, parte significativa de seus mais renomados amigos brasileiros, aqueles que melhor souberam desempenhar concomitantemente os papéis de intelectuais e acadêmicos, renderam-lhe uma expressiva e significativa homenagem com a publicação de Um americano intranquilo, promovida pelo Centro de Pesquisa e Documentação de História Contemporânea do Brasil (CPDOC) da Fundação Getúlio Vargas, que conta com capítulos do amigo e parceiro intelectual Antonio Cândido, do historiador Carlos Guilherme Santos Serôa da Mota, com quem trabalhou no Instituto de Estudos Avançados da Universidade de São Paulo; do historiador e cientista político José Murilo de Carvalho; e do antropólogo Roberto DaMatta, entre outros. 


\section{A ORIGENS PROFUNDAS DE DUAS AMÉRICAS DISTINTAS}

As inquietações de Morse partem de um lugar social, no tempo e no espaço, inusitado e ao mesmo tempo necessário: partem de dentro de uma sociedade - a norte-americana - cujo pensamento acadêmico legitamava sua condição de civilização, diante da barbárie incólume a ser civilizada ou submetida - a América Latina; entendendo as duas situações como etapas correlacionadas. Lugar cômodo, reconfortante e para o qual as perguntas de Morse representavam graves ameaças num tempo em que se reafirmava a superioridade estadunidense em contexto de uma guerra, em essência, entre distintos projetos civilizacionais (comunismo vs. capitalismo).

Para o mundo industrial, o modelo liberal-protestante era alardeado como o mais adequado; enquanto em termos políticos, no afã de cooptar corações e mentes, o modelo anglo-americano propagandeava a si mesmo como mais pluralista. E a Ibero-América, como Morse insistia em designar a América Latina? O que ela representava diante desse pretensamente progressista e antigo mundo novo?

Somente alguém de dentro, no tempo e no espaço, para resistir a essas mensagens de autorreferência valorativa, o que possibilitou uma nova ordem de questionamentos: a ibero-católica nação ibérica seria portadora de modelos anacrônicos e inadequados às novas sociedades? Os homens do sul da América estariam mais ou menos abertos ao novo (os adventos do progresso) em relação aos do norte? Inconvenientes inquietações e que necessitavam de respostas gravemente trabalhosas; isso porque, a resposta de Morse para essas oposições existenciais seriam resultado de escolhas historicamente alocadas.

Suas matrizes foram construídas na primeira parte de que trata o ensaio que estabelece as relações entre Anglo e Ibero-América - América Anglo-Saxônica e América Latina - como portadoras de uma pré-história europeia, o que requereu do autor uma análise retrospectiva. Seria necessário, com isso, ir além das interpretações simplistas que diferenciaram os dois universos apenas como culturas, ou católica, ou protestante, por sua vez, instituições orgânicas ou atomísticas. Seria preciso identificar a matriz moral, intelectual e espiritual comuns à civilização ocidental, cujo período formativo teria ido do século XII ao XVII e que teriam sido incorporadas pelos novos Estados em períodos posteriores.

Nesse período, que inclui o momento em que a América Ibérica era apenas um embrião, constituiu-se o projeto histórico ocidental, com desdobramentos no âmbito tanto filosófico quanto científico. No caso dos Estados Ibéricos, esse projeto foi reformulado mantendo traços deste período formativo para os quais as permanências adviriam já do declínio da sociedade medieval no âmbito da visão cristã, mas cujas hipóteses permaneceram firmes.

À medida que o poder papal declinava na Espanha, crescia em importância o poder de influência das universidades, já em número de 33 no século XVII, integrando-se aos projetos gerais do Estado. Ocorre que, no caso ibérico, não só as universidades não foram anticlericais, como também não constituíram o lócus de ocorrência de nenhuma revolução científica. A visão ordenada do universo, que permeava o pensamento acadêmico dessas primeiras universidades ibéricas, era produto do tomismo, sistema 
filosófico-teológico tributário a Tomás de Aquino (1225-1274), circunscrito, portanto, à cristologia escolástica e que, por meio do probabilismo, subordinava a lógica aristotélica à cosmologia cristã.

Essas características revelariam, para Morse, que os traços de distinção do caso ibérico estariam alocados num campo muito mais amplo de ocorrências do que eventualmente a historiografia tratara. Isso porque as tradições europeias tomaram uma forma muito específica na península ibérica: quase intocada pela Reforma Protestante, pelo Renascimento em sua forma italiana, pela Revolução Científica, pela Revolução Industrial ou pelo Iluminismo, como filosofia moral ou política, elementos que de forma articulada fomentaram revoluções políticas, como no caso da inglesa e da francesa: isso por razões de cronologia, disposição institucional ou por mera geografia.

O desdobramento de uma recusa consciente à influência das revoluções científica e religiosa, caras ao universo anglo-saxônico, foi a renegação tanto da ciência quanto da consciência como instrumentos de construção de provas objetivas e subjetivas da realidade, possibilitanto a permanência de uma autoridade política alicerçada pela tradição e pela doutrina.

Contudo, um componente fundamental na determinação da especificidade ibérica: a influência moçarábica, vigente de 711 (com a invasão árabe à península) a 1492 (com a queda de Granada, marco da Reconquista), é mencionada muito superficialmente por Morse, que não se detém sobre uma análise profunda das transformações operadas naquela sociedade com o advento da cultura árabe e que determinaram traços constitutivos de suas mentalidades, isso porque a tarefa de incorporar povos não cristãos à civilização europeia teria auxiliado a modernidade no caso espanhol, levando à construção de um novo Estado, uma nova visão de mundo e de um novo Homem. $\mathrm{O}$ assédio aos inimigos, primeiro, árabes-muçulmanos e, depois, judeus, fomentou a unidade da cristandade em torno da reconquista por um lado; enquanto, por outro, as contribuições dessas duas civilizações às sociedades ibéricas foi notável. Todavia, não têm, ambos os casos e nas duas perspectivas propostas, tratamento no ensaio de Morse.

A especificidade se daria ainda pelas condições que teriam levado o caso espanhol a se alinhar mais adequadamente ao tomismo, visão coerente e hierárquica do universo, em contraposição à influência do filósofo escolástico John Duns Scot (1226-1308) - ou Scotus - e de seu discípulo, William de Ockham (1287-1347). Em função da predominância desta cosmovisão, as instituições político-religiosas gozavam de maior legitimidade para o cumprimento de um programa nacional estabelecido com muito mais clareza que outros Estados no mesmo século XVI.

A Igreja seria o corpo místico; o Estado, o corpo político e moral; o Homem cristão e/ou natural (na concepção do jusnaturalismo), pagãos ou infiéis, seguiriam sendo capazes de associações políticas.

Sob os reis católicos - Isabel I de Castela (1451-1504) e Fernando II de Aragão (1452 - 1516) - e Tomás de Torquemada (1420-1498), o inquisidor-mor dos reinos de Castela e Aragão, o modelo de sociedade de que tratou Morse não poderia mais ser verificado dado o grau de violência que tomou a Inquisição Ibérica no período subsequente ao século XVII. 
No entanto, para o período, tratava-se de uma visão de mundo moderna estabelecida anteriormente às implicações das revoluções religiosa e científica, ambas externas à península. Isso teria se desdobrado em clivagens fundamentais, perceptíveis na distinção entre América Latina e Anglo-Americana, segundo suas características: os ibero-americanos seriam partidários da doutrina e da ordem social (tributárias ao Antigo Regime), dotados de uma visão compreensiva e unificadora; enquanto os anglo-americanos estariam entregues ao pragmatismo, à regeneração ou autotranscendência, dotados de uma visão empírica de mundo (MORSE, 1988a, p. 48).

Sobre a Revolução Científica, Morse diferenciou o caso ibérico do italiano primeiro pela origem dos cientistas, intelectualmente formados em uma cultura católica que permitia desafiar o monopólio das interpretações eclesiásticas (católicas ou protestantes) em busca da certeza objetiva, enquanto o cientificismo definia-se por seu caráter notadamente anticlerical.

Nesse contexto, a escolha da política ibérica foi feita, para Morse, já na segunda metade do século XVI, também pelo tomismo. Nesse campo político, sob a escolástica tomista pós-clássica, a influência maquiaveliana - notável no restante da Europa - ganhou sua versão espanhola no probabilismo do teólogo dominicano Bartolomé de Medina (1497 - 1585), professor da Universidade de Salamanca e que, em 1577, teorizou-o a partir do princípio básico de que, para questões as quais não houvesse um pronunciamento do magistério da Igreja - definidas então como discutíveis - uma proposição que pudesse ser objeto de prova de que determinada postura seria lícita (moralmente boa, tendo como paradigma a moral cristã), poderia orientar a ação, ainda que a opinião contrária fosse mais provável em termos empíricos, ou seja, seria justificado realizar uma ação ainda que contrária ao saber dominante numa determinada sociedade caso houvesse a probabilidade, ainda que ínfima, de os resultados (a posteriori) serem moralmente bons. Elaborado por um dominicano e incorporado pelos jesuítas como princípio legitimador de suas condutas cristãs (tomistas), a virada absolutista (a "era dos déspotas") que se deu em Espanha a partir do século XVIII, fez com que o probabilismo fosse execrado junto dos jesuítas que o utilizaram para defender a desobediência ao Estado absolutista, motivo pelo qual acabaram caindo em desgraça.

As bases perdidas da legitimidade e da ordem no Velho Mundo teriam sido reconstruídas na América Espanhola apenas durante sua reabilitação pós-colonial, como no caso do Estado chileno de Diego José Pedro Víctor Portales Palazuelos (1793-1837), no século XIX, e da Constituição mexicana de 1917.

Para Morse, haveria, portanto, um desafio: a comparação das tradições políticas ibero-americanas com as anglo-americanas deveria consistir um esforço que superasse as clivagens convencionais entre tomismo e lockeanismo, e cujos imperativos viriam condicionando modelos teóricos e institucionais até os dias de hoje.

No Novo Mundo, os Estados Unidos da América de Thomas Jefferson (17431826) e Alexis-Charles-Henri Clérel (1805-1859) - Alexis de Tocqueville - já teriam demonstrado, ainda que de forma modesta e pragmática, que dariam ao Ocidente uma grande contribuição. 
A escolha política inglesa foi feita na metade do século XVII e, ao contrário do caso ibérico, a opção política anglo-saxã foi diretamente influenciada pelas quatro revoluções: científica, religiosa, comercial e política. Daí o abismo que separariam, no Novo Mundo, dois mundos gravemente distintos, entre um pragmatismo individualista lockeano e um universalismo tomista.

\section{ILUMINISMO, LIBERALISMO E MARXISMO PARA REALIDADES DISTANTES DEMAIS}

Adentrando a história das relações entre Anglo e Ibero-América, as opções políticas tomadas, na realidade que fosse, passariam obrigatoriamente pelo processo de difusão das ideias iluministas na Europa.

Sobre o iluminismo no mundo ibérico, Morse identificou dois períodos fundamentais do chamado século ilustrado na Espanha: o de Benito Jerónimo Feijoo e Montenegro (1676-1764) - Benito Feijoo; e o de Baltasar Melchor Gaspar María de Jove Llanos y Ramírez (1744-1811) - Gaspar Melchor de Jovellanos. Contudo, o pensamento ilustrado na Espanha seria mais um mosaico do que um sistema, não demonstrando nenhuma possibilidade ou perspectiva de fusão.

A emancipação política da América Espanhola, nesses termos, antes de ter estado conectada a ideologias provenientes do Ocidente moderno, politicamente convulsionado, teria raízes profundas nas tradições espanholas medievais, motivo pelo qual a independência da América Hispânica levou à desagregação da tão sonhada unidade bolivariana à circunscrição dos interesses das famílias de elites crioulas.

Sobre a constituição social ibero-americana, em contraposição à constituição étnica dos EUA, a origem indígena e o componente africano configurando uma expressiva parcela da população, aliados à mobilidade espacial e ao crescimento populacional pelo viés da miscigenação, deram a esta constituição grande diversidade de tipos sociais, catalizados na mestiçagem (a partir da qual despontam elites crioulas) e polarizados entre civilizados \& bárbaros, num conflito social que assume a dimensão espacial na clivagem entre campo e cidade. Ao contrário, a condição extrassocial dos escravos e depois dos libertos nos EUA, aliada à quase total ausência do indígena aniquilado (fenômeno que sequer é citado por Morse), condicionaria uma visão social mais consistente pela ausência da diversidade.

Morse observou que, ainda que marcada pela diversidade, a bipolarização da constituição cultural ibero-americana entre civilização $\&$ barbárie não teria sido invenção de Domingo Faustino Sarmiento Albarracín (1811-1888), na Argentina da década de 1840; mas já estaria firmemente consolidada como recurso explicativo da condição latino-americana desde o frei espanhol José Antonio de San Alberto (1727-1804), na década de 1780, passando por Simón José Antonio de la Santísima Trinidad Bolívar y Palacios Ponte-Andrade y Blanco (1783-1830) - Simón Bolívar -, na década de 1820. A barbárie aparecia dos campos ermos dos gaúchos ao litoral dos pescadores da Colômbia idealizada, que contrapunha o projeto de incorporação social ibérico a uma elite que não desejaria se integrar. 
O autor impôs uma polêmica interpretação sobre os movimentos migratórios, dados como política de Estado para países latino-americanos no século XIX, de que não se trataria de forma alguma de expressão de racismo apenso a políticas de branqueamento o que, para ele, prefiguraria explicações simplistas sobre um fenômeno que, em essência, consistiria uma tentativa de dar corpo político a uma constituição social demasiadamente diversa.

A questão é que nem todas as nacionalidades tiveram sua entrada franqueada em países latino-americanos, tendo havido uma notória predileção por alemães e italianos, muitos que fugiam das tardias guerras de unificação nacional que marcaram o início da década de 1870, dentre eles anarcossindicalistas e dissidentes de vários matizes que tentavam escapar de perseguições políticas.

A emancipação política teria levado a Ibero-América a experimentar uma emancipação também no campo das mentalidades, o que nos dizeres do filósofo mexicano Leopoldo Zea Aguilar (1912-2004) teria levado à renúncia da dialética com o passado, impedindo no século XIX sua superação, daí algum caráter de continuidade na percepção de Morse.

As independências ibero-americanas, nessa visão, não teriam sido capazes de construir sua unidade política em função da carência de uma ideologia hegemônica que tivesse plena aceitação ou aquiescência pacífica. Para isso, nem a visão ibérica nem a anglo-francesa de mundo teriam sido capazes de construir a homogeneidade necessária ao projeto bolivariano de Grã-Colômbia.

Ainda que não tivesse sido homogeneizada economicamente, encarnada num poder soberano ou cimentada identitariamente, essa emancipação mental teria sido relativamente partilhada pela intelectualidade nas décadas de 1820 e 1830. Antes disso, já desde a década de 1760 e estendendo-se até 1840, a ilustração hispano-americana teria se estabelecido por meio da incorporação acrítica das influências estrangeiras. Especificamente, no caso espanhol, limitou-se a uma ilustração católica inconclusa, uma espécie de modernização pela metade e, nas universidades, aparecia subordinada tanto à razão quanto à autoridade.

O resultado foram as luzes na Hispano-América, tendo como agentes promotores predominantemente crioulos, determinando, por sua vez, sua correspondência com um profundo sentimento religioso, com o republicanismo rousseauniano, com o liberalismo oligárquico e com o princípio de incerteza que vigorou até as guerras de independência e compreendeu um "giro" no pensamento político latino-americano (em Bolívar, por exemplo; e na geração de 1837, na Argentina).

Para Leopoldo Zea, nestes termos, o pensamento ibero-americano teria ficado, conforme corroborou Morse, à deriva no século XIX, voltando a descobrir seus fundamentos apenas no século XX. Isso porque, neste período de 1760 a 1840, a intelectualidade ibero-americana não teria tido condições de construir uma ideologia hegemônica, restrita como estava a um número bem menor de autores que a intelectualidade francesa.

No âmbito do pensamento político-social, a contraposição se daria entre o ibero-americano desordenado e o anglo-americano instrumentalizado. 
A desordem ibero-americana teria se dado, segundo Morse, por conta de condições mundiais, dentre as quais: o secularismo, o nacionalismo e a expansão capitalista que teriam, por sua vez, dado abertura para o liberalismo, para a democracia e para o marxismo, para uma formação social diversa daquela de sua origem e que não contava com pensadores de primeira grandeza para sistematizá-los, como o filósofo e economista inglês John Stuart Mill (1806-1873) e Tocqueville, por exemplo. Liberalismo e democracia não teriam sido termos correlatos e interdependentes na Ibero-América, tendo sido assimilados de forma não só independente, mas intermitente; enquanto na Anglo-América, sua coexistência teria levado à continuidade da dialética liberdade-ordem.

O liberalismo, sempre uma importação problemática, não poderia florescer como sistema político senão numa sociedade liberal (VIANA apud. MORSE, 1988a, p. 92). Apesar disso, a influência liberal na Ibero-América foi notável como no caso da independência mexicana, para a qual tradições como a rousseauniana foram extremamente caras.

Nesse mesmo ambiente, se deu o problema do marxismo, caracterizado logo de início pela ausência de referências à América Latina na obra de Friedrich Engels (18201895) e Karl Heinrich Marx (1818-1883). Pode-se dizer que o precursor do marxismo latino-americano tenha sido, conforme corrobora Morse, o argentino Juan Bautista Justo (1865-1928), que traduziu o primeiro volume de O Capital, publicado no jornal La Vanguardia, e foi dirigente do Partido Socialista Argentino (filiado à Segunda Internacional). Teve grande influência no Brasil e no Uruguai, desta feita, em toda a nascente esquerda latino-americana.

Contudo, a influência do anarcossindicalismo trazido por imigrantes primordialmente italianos, por conta das preexistentes afinidades ibéricas aos populismos (herdeiros de traços já presentes no caudilhismo) foi, de início, muito maior. Daí a simpatia e engajamento de intelectuais mais com o anarquismo que com o socialismo, como no caso do peruano José Manuel de los Reyes González de Prada y Álvarez de Ulloa (18441918) e tantos outros.

A ocorrência da Revolução Russa em 1917 é que mudou a condição da influência socialista na América Latina. Morse comparou o marxismo russo, que obteve sucesso em sua reelaboração orientalizada e russificada, com o caso da Ibero-América que não conseguiu sua versão indígena por conta dos custos que a intelectualidade americana teria que arcar por seu engajamento, ao contrário do caso anglo-americano, que empacotava essas ideias fazendo-as circular como mercadoria e sem pressupor, de igual forma, nenhum engajamento concreto.

A concepção marxista sobre a estratificação social, bem como do motor dialético da história na forma da luta de classes, precisava ser revista para se adequar à realidade ibero-americana. Para Andrés Molina Enríquez (1868-1940), sociólogo mexicano positivista e crítico do período revolucionário, tratava-se de classes de interesses, com um sentido socioétnico em construção numa ordem social que ainda se afirmava.

A fusão entre imperativos ocidentais e a realidade ibero-americana seria feita apenas a partir do intelectual peruano José Carlos Mariátegui La Chira (1894-1930) e seu 
conceito de Indo-América, elaborado sob forte influência do marxismo italiano de Benedetto Croce (1866-1952) e de Antonio Gramsci (1891-1937), que o levou a reformar o marxismo para adaptá-lo à realidade peruana e, por extensão, indo-americana.

\section{AS BASES DO NOVO OCIDENTE}

$\mathrm{Na}$ "sombra do porvir" de Morse, a Ibero-América teria sua própria cultura, mais ocidental que a Anglo-América, onde Velho e Novo Ocidente se encontrariam pela penetração do "desígnio ocidental". Em síntese: a penetração do Novo Ocidente na Ibero-América teria sido irregular, tanto no nível popular quanto intelectual.

Disso decorreriam paradoxos. O primeiro seria o do pluralismo, cuja ideia aceita é a de que os EUA seriam pluralistas enquanto a América Latina inclinada a regimes autoritários e monolíticos, e cuja constatação seria a de que, por sua abertura à conjuntura política, os ibero-americanos é que seriam mais pluralistas. E o segundo, o da estrutura de caráter, cuja ideia aceita é a de que a solução liberal-protestante teria sido mais adequada para o mundo industrial do que a ibero-católica, enquanto a constatação feita é a de que a mentalidade ibero-americana teria sido capaz de pensar o conjunto de sua sociedade em perspectiva, enquanto o anglo-americano não possuiria a mesma capacidade de se autorreferir criticamente. A obediência voluntária e ativa ao poder constituído ou à doutrina prescrita teriam feito com que o livre-arbítrio, na Ibero-América, fosse auto-ordenado, caso da monarquia barroca na Espanha, do Brasil de D. Pedro II (18251891) etc. (MORSE, 1988a, p. 39-143).

Segundo a crítica de Morse ao pensamento intelectual americanista, não nominado, seus intelectuais (para ele "decadentes" em "universidades decrépitas") não teriam sido capazes de perceber que novas sínteses culturais autênticas contribuíram com as bases do Novo Ocidente. Sua crítica atinge mais objetivamente a cliometria, o etnocentrismo, a história comparativa e o a-historicismo da academia norte-americana.

Essa crítica ganharia forma mais consistente no artigo Brazilianists, God bless' em! What in the world is to be done?, escrito em 1981 a pedido do historiador britânico Kenneth R. Maxwell, um dos mais importantes brasilianistas ${ }^{(2)}$, presidente da Associação de Brasilianistas e que convidara Richard Morse, que nunca se considerou um brasilianista, a palestrar sobre a situação dos estudos brasileiros nos EUA, oportunidade na qual apontou uma série de "hipocrisias" ("Uma entrevista com Richard Morse", 1989, p. 87).

Sua maior crítica em relação aos brasilianistas consiste na ideia de que:

... tudo o que foi feito no Brasil antes da chegada dos brasilianistas é um pouco antiquado, impressionista. No entanto, os livros de Gilberto Freyre, Caio Prado, Sérgio Buarque de Holanda, forneceram matrizes intelectuais para o conhecimento do Brasil. Os brasilianistas não dão isso, eles dão informação. Se você pegar os estudos de Fernando Henrique Cardoso,

(2) Publicou o importantíssimo, A devassa da devassa - A Inconfidência Mineira: Brasil e Portugal 1750-1808. São Paulo: Paz e Terra, 1985. 
Otávio Ianni, Florestan Fernandes, principalmente sobre São Paulo, Santa Catarina, Paraná e Rio Grande do Sul, feitos mais ou menos na mesma época que os dos brasilianistas, aí também você terá hipóteses sobre o funcionamento da sociedade. Os americanos vêem isso de maneira preconceituosa, como "ideias marxistas", mas esses autores conseguem dar vida à sua história, o que eles fazem é uma aventura intelectual. ("Uma entrevista com Richard Morse", 1989: 88.).

Haveria uma profunda distinção, nesse caso, entre trabalho acadêmico e trabalho intelectual, mais grave para o caso norte-americano ${ }^{(3)}$, mas cujo mal (o da modernidade) já poderia ser sentido amargamente nas universidades brasileiras (MORSE, 1983, p. 1-11).

\section{ONTOLOGIA E AXIOLOGIA DO ENSAIO MORSEANO}

Tentando um exercício de tipificação ontológica do autor, ao optar por não vitimizar a América Latina em suas relações com os EUA e por determinar o espelho como alegoria maior do anverso e reverso que opõem e correlacionam o mundo anglo-saxônico ao ibérico, Morse difundiu a convicção de ter superado as correntes anteriores que se debruçaram sobre os estudos das relações interamericanas. Criticou, com isso, uma série de determinismos por não terem se interessado pelos projetos civilizadores que elevariam as mentalidades à condição de fatores determinantes nessas relações. O sentido foi o de estabelecer a Ibero-América como opção cultural à Anglo-América, num momento em que esta passaria por uma crise de autoconfiança.

Essa percepção é agudizada pelo histórico anterior. Na tentativa de compreender a influência dos EUA nas relações interamericanas, via de regra, a produção historiográfica esteve focada em dinâmicas econômicas, estruturas políticas e no histórico de intervenções militares estadunidenses, chegando a explicações superestruturais dessas relações, desde o determinismo geográfico - nos primórdios evolucionistas das Ciências Humanas -, o binômio "civilização É barbárie" - no auge do positivismo - e os desafios impostos pela modernização.

Ao exaltar o trabalho do sociólogo estadunidense Robert Neelly Bellah (1927-2013) (MORSE, 1988a, p. 26), que propôs uma explicação sobre a sociedade anglo-americana excluindo as variáveis sociais e econômicas e interpretando-as pelo viés da cultura, Morse justificou porque essas dimensões, pensamos que fundamentais da vida social, aparecem com importância residual em sua análise. Para ele:

o problema não é o que determina o que, mas reconhecer que a explosão capitalista-científica, originalmente alimentada, quando não 'determinada', por imperativos morais e religiosos, adquiriu impulso próprio e, há dois séculos pelo menos, vem corroendo esses imperativos originais. (MORSE, 1988a, p. 27).

(3) Para Morse, isso não se estenderia a todos os brasilianistas, dos quais poderia-se excluir, pela excelência do trabalho intelectual, o próprio Kenneth Maxwell, além de Joseph Leve e Ralph de la Cava. 
Informou-nos ainda Morse que, desde seus primeiros estudos sobre a cidade de São Paulo, optou por uma orientação culturalista, “... sem dar muita atenção à dialética da história" ("Uma entrevista com Richard Morse", 1989, p. 78).

Ontologicamente, a convicção de superação das correntes "unicausais" anteriores pode ter levado Morse a desconsiderar fatores como as dinâmicas econômicas que alicerçaram os interesses entre Norte e Sul da América.

Utilizando suas próprias palavras, a cultura "... é uma coisa quase autônoma, que tem sua vida própria" ("Uma entrevista com Richard Morse", 1989, p. 81). Isso, para se referir aos problemas colocados para a cultura ocidental pela própria democracia, e que a América Latina não teria dado conta de resolver. Para Morse, a resolução desses problemas não esgotaria a questão da cultura uma vez que, para ele, as mentalidades seguiriam obedecendo suas características endógenas, por isso, seu autonomismo em relação à política e à economia. Afirmou que os EUA teriam resolvido, por exemplo, "todos os seus problemas", tendo os alicerces de suas mentalidades obedecido mais à ideia de democracia do que dos problemas decorrentes dela.

O autonomismo defendido por Morse poderia, segundo nossa proposição, ter chegado à própria unicausalidade que tentou evitar. Por exemplo, ao designar aqueles que trataram do período formativo do século XII ao XVII como "varejistas acadêmicos" (MORSE, 1988a, p. 26), por qualificarem-no como de ocorrência da urbanização, ascensão da burguesia, consolidação dos Estados Nacionais, diversificação religiosa, desenvolvimento capitalista, expansão ultramarina e cientifização da visão do cosmos do Homem, a pergunta que se deve fazer é se, por conta do determinismo professado por essas correntes (se é que teriam sido de fato deterministas), por acaso o período tenha deixado de ser o da urbanização, da ascensão da burguesia, da consolidação dos Estados Nacionais, da diversificação religiosa, do desenvolvimento capitalista, da expansão ultramarina e da cientifização da visão do cosmos do homem?

Evidentemente o problema identificado por Morse é o da determinação, por isso, sua abordagem, segundo ele mesmo referiu, não se trata de uma inversão da perspectiva marxista, buscando determinar a economia pela cultura; mas determinar o que hoje se refere às mentalidades; mas, para Morse, as "... mentalidades de pessoas inteligentes ..." ("Uma entrevista com Richard Morse", 1989, p. 78), que apesar de referir não se preocupou em definir, restringindo-se à literatura. Evidentemente a literatura expressa as mentalidades de seu tempo; contudo, a partir de uma perspectiva dirigida, determinada por emissor, receptor, âmbito de circulação de suas mensagens e, primordialmente, pela função social do texto. Para além de sua difusão posterior, esses elementos é que lhe dão forma e conteúdo, revelando uma determinada visão de mundo dentre várias.

Schwartzman designou a escolha de Morse pela análise literária para determinação das mentalidades como a "tese da superioridade dos novelistas sobre os cientistas sociais", que exemplificou como se:

... autores tão herméticos e quase incompreensíveis como Cortázar, Borges ou Guimarães Rosa possam ter algum papel na constituição de novas ideologias de alcance popular. A falsa polarização entre "novelistas" e "cientistas sociais" que Morse introduz só pode produzir 
efeitos no mundo restrito dos círculos acadêmicos de elite, para consumo dos quais, afinal, ela parece ter sido feita (SCHWARTZMAN, 1997, p. 24).

Por exclusão, ao designar os literatos como "inteligentes", podemos pensar quais categorias de atores sociais poderiam ter passado desapercebido por Morse. A postura resultaria na anulação de uma gama diversa de fontes como aquelas sobre o movimento operário em São Paulo, que reclamou o próprio Morse ao referir-se à ausência de documentos que permitissem recuperar episódios importantes dessa expressiva força política e social ("Uma entrevista com Richard Morse", 1989, p. 78). Evidentemente, Morse havia privilegiado a literatura e, mais do que isso, parte dela, uma vez que a própria imprensa operária constitui um dos mais significativos meios de vocalização dos interesses desse imprescindível segmento de sociedade, para aqueles desejosos de compreender as sociedades que compuseram no período de sua existência.

Contudo, Morse era, essencialmente, um estudioso que trabalhava na fronteira entre História e Literatura. O risco é o de relacionar sua opção estreitamente à influência exercida pelo grupo com o qual manteve contato mais intenso quando de sua permanência em São Paulo, essencialmente Antonio Cândido e Sérgio Buarque de Holanda; isso porque sua opção pela literatura já havia sido tomada anos antes, nos EUA.

Seu interesse pela literatura data ainda de seu período de graduação, no qual assistiu aos seminários promovidos pelo ensaísta John Orley Allen Tate (1899-1979) e pelo crítico literário Richard Palmer Blackmur (1904-1965), professores que ofereciam seminários para alunos interessados em literatura e que, pela exegese de textos que empreendiam, foram incorporados posteriormente à new critic, tendência cujo nome remonta ao título do livro do poeta e crítico John Crowe Ransom (1888-1974), The New Criticism, de 1941.

Influência maior teria exercido o professor Jacques Martin Barzun (1907-2012), historiador das ideias e da cultura que, durante a pós-graduação de Morse, chamou-lhe a atenção para a interdisciplinaridade dos estudos culturais e que, por meio de expressões intelectuais e culturais, seria possível explicar aspectos os mais variados das sociedades, fossem políticos ou, até mesmo, relacionados à teoria econômica. Já ao professor espanhol Augusto Centeno, Morse deve a apresentação de autores latino-americanos fundamentais em seus estudos posteriores.

Seu orientador de tese, o historiador e sociólogo Frank Tannebaum (1893-1969), também lhe chamava a atenção para as relações entre história latino-americana e literatura, perspectiva que foi apenas aprofundada no Brasil.

Contudo, Morse esclareceu que, na realidade brasileira, havia uma comunidade de intelectuais trabalhando literatura e questões culturais, na ciência histórica; enquanto nos EUA esses estudiosos encontravam-se guetoizados, em especial, aqueles que estudavam temáticas relacionadas à América Latina, motivo pelo qual historiadores tomaram demasiado cuidado para não se tornarem latino-americanistas.

Em termos teóricos, a mais forte presença no pensamento de Morse, para explicar o "jogo de espelhos" que empreendeu na contraposição entre Ibero e Anglo-América, não 
é histórica ou histórico-filosófica, senão sociológica, mais especificamente se trata da sociologia alemã de Maximillian Carl Emil Weber (1864-1920) - que penetra de forma relevante a história -, com a qual tomou contato quando já era professor, em 1949, na Universidade de Columbia, passando a utilizar seus pressupostos teóricos em seus estudos sobre a América Latina. Contudo, não se trata do momento definidor do modelo que aplicaria na elaboração de $O$ Espelho de Próspero, senão de sua fase posterior aos primeiros ensaios sobre a cidade de São Paulo que, segundo o próprio Morse, por conta da extrema influência weberiana, careciam de dialética.

Do contato com o marxismo não resultou tão somente a possibilidade de elaborar análises dialéticas, mas aproximou-lhe da Escola de Frankfurt, de Theodor Ludwig Wiesengrund-Adorno (1903-1969) e de Max Horkheimer (1895-1973) que, junto da obra de Michel Foucault (1926-1984), deram-lhe formas explicativas para estruturas de dominação que, para além do universo institucional, já tratavam da dimensão da cultura como fenômeno de massa, bem como dos processos mentais envolvidos na tomada de consciência sobre uma determinada realidade estrutural.

De qualquer forma, no Espelho de Próspero, ainda que por meio de um jogo dialético (o jogo de espelhos), Weber ainda seria fortemente perceptível no recurso à exaltação (ou idealização) de uma Ibero-América que, distencionada do tradicionalismo patrimonialista, tomista e universalizante depurado da Inquisição, do despotismo e da presença moçarábica e judaica, seria tipo ideal para o contraste "terapêutico" com a Anglo-América.

A associação com Weber provocou da crítica a acusação de que Morse estaria engajado a uma historiografia norte-americana conservadora, à qual a resposta dada foi a de que tampouco é possível associar Weber a uma historiografia conservadora nos EUA, bem como resulta difícil localizar a influência de Weber sobre a produção acadêmica norte-americana.

Talvez não somente Weber, mas a própria filosofia alemã estivesse mais inclinada às sistematizações (GALVAN, 1986, passim) e explicasse o esforço sistematizador empreendido por Morse ao relacionar o catolicismo medieval e o colonial não como teologia, todavia, como uma visão intelectual e coerente de mundo; não sistêmica, mas arquitetônica ("Uma entrevista com Richard Morse", 1989, p. 86).

\section{EXISTIRIA UMA IBERO-AMÉRICA?}

Outro ponto a ser levantado é o de que a Ibero-América, para Morse, seria herdeira da tradição espanhola somente. O caso lusófono não possuiria, nesses termos, especificidade; desta feita, uma distinção fundamental para a compreensão da realidade latino-americana também não apareceria: a distinção entre América Espanhola e América Portuguesa.

Nosso estranhamento se dá mais gravemente pelo fato de as clivagens estarem claramente dadas no clássico conhecido por Morse e de seu mui próximo amigo, Sérgio Buarque de Holanda (1936), no capítulo 4, O semeador e o ladrilhador, de Raízes do Brasil. 
Segundo o professor Francisco Falcon (in: CÂNDIDO, 1992, p. 23-24), o “compromisso ibérico" referido por Morse estaria comprometido pelo restrito e problemático uso do termo "ibérico", restrito como dissemos à Espanha.

Um "ibérico", diga-se de uma vez, dos mais problemáticos, uma vez que, a rigor, o que nós temos aqui é apenas a Espanha; Portugal mesmo só aparece no texto de maneira muito insuficiente (...). Assim, é a parte espanhola que responde de fato por esse "compromisso ibérico" (...). O que Morse não nos diz, em resumo, é que a "Ibéria" evitou as "revoluções grandes" (a religiosa e a científica), muito embora "estivesse aberta" (?) a tendências provenientes de todas as partes da Europa, tampouco sendo possível encará-la como um caso de desenvolvimento interrompido ou bloqueado.

Ainda que haja visões de mundo partilhadas entre as realidades portuguesa e espanhola, distintas sociedades tomaram lugar em diferentes empreendimentos coloniais, com finalidades por vezes contrapostas. Ainda que Morse se esquive ao avisar os incautos de que sua preocupação era, em verdade, com as metaestruturas, e que os acidentes da história não lhe interessariam, as clivagens apontadas por Falcon (in: CÂNDIDO, 1992, pp. 23-24) excedem o acidental:

Sempre desconfiamos muito sempre que uma proposta de interpretação do mundo ibérico fica restrita de fato à Espanha, embora compreendamos, talvez até porque não estamos na pele dos historiadores lusos, que existem certos hábitos mentais, ou intelectuais, cuja expressão mais comum neste lado de cá do Atlântico consiste na simplificadora fórmula conhecida por "América Latina", hábitos estes que levam a subsumir a história portuguesa na espanhola. Nesta inteligente síntese que Morse construiu, Portugal não se faz presente. Isso nos leva então de volta a certas advertências (...), a propósito dos perigos que rondam o historiador toda vez que ele se dispõe a enveredar pelo caminho aparentemente lógico das extrapolações e deduções hispano-lusitanas.

\section{A DIALÉTICA DO JOGO DE ESPELHOS}

O que explicaria o fato de $O$ espelho de Próspero nunca ter sido lançado no mercado editorial estadunidense seria, segundo Morse, o fato de ter utilizado o jogo de espelhos para criticar a cultura norte-americana, contrastada do fundo reluzente da América Latina. Para Morse, uma história ainda evolucionista e que se debruça sobre teses de excepcionalismo, profundamente ideológica em termos civilizatórios, não teria nada o que aprender com a América Latina; lógica que foi invertida por Morse, que apontou justamente para as lições que os EUA deveriam reter do magistério latino-americano.

Disso teria resultado a recusa de editores, nos EUA, para a publicação do livro, valendo-se de critérios mais sentimentais do que políticos; o que se somou ao seu formato ensaístico e que resultou também na recusa das University Press americanas pela carência de densidade teórica e percursos explicativos que, em termos epistemológicos, culminassem em prova empírica das muitas assertivas ali impressas, ou seja, requeria-se a estrutura de tese e não de ensaio. 
Daí podemos aferir que o livro, conforme nos disse o próprio Morse, não tinha como receptor primordial o público latino-americano, pelo contrário, teria sido escrito, com fins "terapêuticos"(4), para o público norte-americano. Irônico, senão extremamente significativo, foi o fato de o livro não ter sido publicado pelo mercado editorial norte-americano e, além disso, ter repercutido de forma tão polêmica no mercado editorial que o consumiu, essencialmente acadêmico, no Brasil.

Com a publicação de $O$ Espelho de Próspero, a América Latina, na forma da Ibero-América dada por Morse, ganhava a condição de "tipo ideal" no método analítico weberiano, modelo no qual a sociedade norte-americana passava a ser analisada por meio daquilo que não possui, segundo um modelo ideal e, conforme grande parte da crítica, idealizado na forma latino-americana. Existiriam, portanto, numa sociologia weberiana da História, matrizes comparáveis em todas as sociedades e culturas, não importando o quão mais diversas fossem ${ }^{(5)}$.

$\mathrm{Na}$ associação da América Latina ao modelo ideal de Weber, numa espécie de ensaio sociológico da História, Morse, segundo a crítica, teria escapado de temas espinhosos como a recentíssima ditadura militar que, ao tempo de sua publicação no México ensaiava alguma abertura e, quando publicado no Brasil, fazia sentir sua imediata herança maldita na forma dos gravíssimos problemas que assolaram o Brasil em termos sistêmicos (inflação, corrupção, crise econômica, desemprego, violência, impunidade etc.). Contudo, Morse (1989, p. 166-178) argumentou que sua preocupação não teria sido conjuntural; mas estruturalizante.

A questão, para a socióloga Helena Maria Bousquet Bomeny (in: CÂNDIDO, 1992, p. 04), era a de que o otimismo da tese do espelho vinha sendo equivocadamente criticado, uma vez que:

A resposta que Morse dá aos seus críticos é uma reafirmação da abordagem histórico-cultural de longa duração, ou seja, de processos mentais fundantes que não podem ser definitivamente comprometidos por indicações empíricas dos constrangimentos do dia a dia. Morse está preocupado com tendências gerais típico-ideais que, embora depuradas e abaladas pelos fatos da conjuntura, se mantêm como traços característicos de processos culturais mais amplos.

Segundo Carlos Guilherme Mota, é exatamente essa postura que distancia gravemente Morse dos brazilianistas e que explica sua recusa em vestir-se dessa designação: "... salvo discretas exceções, [os brasilianistas] tornaram-se experts em épocas e temas demasiado limitados. Raramente alcançam patamar da reflexão em torno de civilizações ..." (in: CÂNDIDO, 1992, p. 38).

(4) O termo é utilizado por Morse ("Uma entrevista com Richard Morse", 1989, p. 82) da seguinte forma: "O espelho foi escrito para o público norte-americano realmente como uma terapia...", ou seja, com a finalidade de provocar reflexões sobre o modus vivendi norte-americano, contrastando seu modelo de sociedade daqueles abstraídos das sociedades ibero-americanas.

(5) Dada a importância dessa afirmação, convém transcrever a própria pergunta feita à Morse ("Uma entrevista com Richard Morse", 1989, p. 84), seguida de sua titubeante resposta: "Você acredita então na existência de uma matriz comparável em todas as sociedades, não obstante a diversidade das culturas? - Acho que sim". 
Na crítica que empreendeu Schwartzman (1997, p. 37), haveria um equívoco primordial na utilização da alegoria do espelho, sendo assim do método dialético, para o estudo da constituição "ibero-americana" por contraste em relação à "Anglo-América":

... a América Ibérica está desfocada porque ela se contempla no espelho da próspera América inglesa e, na busca inútil da imitação do outro, perde sua própria essência. Os latinos não percebem que o liberalismo, a democracia representativa, o racionalismo, o empirismo científico, o pragmatismo, todos estes ideais alardeados pelos ricos irmãos do Norte não só são incompatíveis com a realidade mais profunda da América Ibérica, como também marcam a decadência e a falta de sentido da própria sociedade capitalista e burguesa que os criou.

Há ainda implicações de ordem teórico-metodológicas, haja vista que a aplicação do "ideal tipo" weberiano, no jogo de espelhos, pode comprometer a análise quando balizas temporais não são devidamente calibradas para distintas realidades ou quando as próprias diferenças deixam de ser relativizadas. $\mathrm{O}$ modelo ideal deixaria de responder, chegando mesmo a produzir análises distorcidas e anacrônicas no contraste com formações sociais distintas (consideradas inconclusas), resultando na percepção sobre deficiências que só existem em razão da comparação insistentemente feita com o tipo ideal, ou seja, apontando para sociedades que poderiam ter sido ou poderiam ser o que jamais desejaram.

Um ano depois da publicação de $O$ Espelho de Próspero, respondendo à parte das críticas que já caíam sobre a obra, Morse (1988a, p. 82) demonstrou mais gravemente a ocorrência deste tipo de distorções no jogo de espelhos ao contrastar Prússia e Paraguai; Atenas e Recife ou Tegucigalpa. Senão, vejamos: "Havia a Prússia, com uma forma de governo um pouco como a do Paraguai de hoje. Foi precisamente pela impossibilidade da situação de uma Alemanha inexistente que surgiram um Hegel, um Kant, um Goethe e, no campo da música, um Beethoven." E antes que nos perguntemos onde estariam as expressões paraguaias de Hegel, Kant, Goethe e Beethoven, Morse (1988a, p. 82) se adianta: "não estou dizendo com isso que surgirão ou que se deva cultivar grandes gênios na América Latina - talvez não seja mais uma época de gênios.”

O problema da alegoria do espelho seria o de tomar as identidades sociais "ibero-americanas" por reflexo das imagens do norte. Para Schwartzman (1997, p. 37):

... outro próspero encontra sua redenção na contemplação do mundo latino, ou mais precisamente, na busca quase heróica de sua essência perdida. É na tradição ibérica, nos diz Morse, pela sua fidelidade à busca de uma visão abrangente e unificadora do mundo, pela crença profunda, mesmo que inconsciente, em uma realidade social que transcende o indivíduo e é mais que o somatório dos interesses individuais e suas servidões, que se poderia encontrar uma resposta adequada à crise moral e existencial do mundo anglo-saxão, e, por reflexo, da América Latina. Não haveria, no entanto, razões para espanto, porque disto se trata, afinal, no jogo de espelhos: de buscar constituir a própria imagem na contemplação do outro, e dar ao outro, ao mesmo tempo, a ilusão de que, porque ele se percebe no primeiro, ele também existe.

Logo depois de Morse ter concedido entrevista à revista Estudos Históricos, do Centro de Pesquisa e Documentação de História Contemporânea do Brasil, da Fundação 
Getúlio Vargas, publicada somente em 1989 (quase um ano depois da realização da entrevista em que Morse rebatia as primeiras críticas), publicou na revista do Instituto de Estudos Avançados da Universidade de São Paulo o artigo Notes toward fresh ideology (1988), no qual respondia a questões que argumentava pertinentes ao hiato entre os anos de 1982, em que a obra fora publicada pela primeira vez no México, e 1988, de sua publicação no Brasil.

No artigo, Morse (1988b, p. 14-43) reconheceu algum determinismo em seu jogo de espelhos, elaborado em um ensaio como tese, do que resultaria em contradição. A crítica sobre a supervalorização das ideias tomistas pós-medievais, bem como uma eventual defesa do patrimonialismo tomista, para Morse, tiveram a resposta de que se tratava de manifestações da época que criou esses sistemas e que se contrapunham aos valores ingleses. Não que o modelo ibérico tivesse sido de alguma forma democrático, mas teria sido, por contraste com o modelo inglês, portador de traços democráticos lidos como ameaçadores pela própria Inglaterra.

Para Helena Bomeny (in: CÂNDIDO, 1989, p. 03), o jogo de espelhos seria uma "troca simbólica" num "mercado de emoções":

... os intelectuais brasileiros emprestavam a Morse o passaporte com o qual poderia penetrar sua cultura, e o historiador americano oferecia aos latinos, desapontados com suas próprias realidades, uma perspectiva compreensiva, de longo prazo, que relativiza, e quem sabe suaviza, os urgentes, estranhos, espinhosos e nada promissores caminhos cotidianos de nosso percurso cultural.

\section{CONSIDERAÇÕES FINAIS}

Sobre o impacto em torno da publicação do ensaio, voltando o espelho contra aquele que busca definir sua identidade e impondo o reflexo do outro no fundo reluzente do Espelho de Próspero, Richard Morse relativizou o conceito de civilização, ainda agarrado ao argumento historiográfico por décadas posteriores ao suposto desmoronamento do evolucionismo spenceriano, revisando com isso o próprio conceito de civilização; por conseguinte, auxiliou consubstancialmente na edificação de um moderno conceito tanto de cultura como de mentalidades.

Conforme observara Carlos Guilherme Mota, a publicação de O Espelho de Próspero representou um revigor essencial a viciados círculos acadêmicos, restabelecendo o próprio gênero ensaístico como meio primordial de reflexão política e social, conectado a uma antiga tradição que encontrava nele a ponta da caneta de um homem do norte e que fazia questão de não se referir como latino-americanista ou brasilianista, não por mera propositura semântica, mas por seus profundos significados.

Pensamos que não se pode dizer, como afirmara Schwartzman (1997, p. 37), que "se trata de um livro profundamente equivocado e potencialmente danoso em suas implicações”. De fato, no ensaio, nos parece que a realidade empírica é irrelevante, mas o próprio Morse fez questão de esclarecer, corroborando a impressão, que o que estaria em jogo seriam os princípios organizadores do corpo político, e não seus resultados. 
No entanto, a questão primordial é que as conclusões de Morse foram obtidas pioneiristicamente a partir de visões de mundo - o que se celebrou contemporaneamente como uma História das Mentalidades -, e não por manifestações meramente institucionais.

Nos processos de significação e de ressignificação da obra, dados pelo debate historiográfico, antes de nos perguntarmos sobre edifícios erigidos, não seria mais adequado perguntarmos o que foi demolido?

\section{BIBLIOGRAFIA}

CÂNDIDO, Antonio (org.). Um americanointranqüilo. Rio de Janeiro: Fundação Getúlio Vargas, 1992. GALVAN, Francisco. Max Weber: elementos de sociologia. México: Universidad Autónoma Metropolitana, 1986.

HOLANDA, Sérgio Buarque de. Raízes do Brasil. Rio de Janeiro: José Olympio, 1936.

MAXWELL, Keneth. A devassa da devassa - A Inconfidência Mineira: Brasil e Portugal 1750-1808. São Paulo: Paz e Terra, 1985.

MORSE, Richard. Toward a theory of Spanish American Government. Journal of the History of Ideas, V. 15, n. 01, 1954.

MORSE, Richard. The Heritage of Latin America. In: HARTZ, Louis (et al.). The founding of new societies. New York: Harcourt, Brace and World, 1964.

MORSE, Richard. Brazilianists, God bless'em!: what in the world is to be done? Stanford: Stanford-Berkeley Joint Center for Latin American Studies, 1983.

MORSE, Richard. O Espelho de Próspero: Cultura e idéia nas Américas. São Paulo: Cia. das Letras, 1988, "a".

MORSE, Richard. Notes toward fresh ideology. Revista do Instituto de Estudos Avançados da Universidade de São Paulo, V. 2, n. 02, São Paulo, maio/ago, 1988, "b".

MORSE, Richard. A miopia de Schwartzman. Novos Estudos CEBRAP, n. 24, jul. 1989.

RODÓ, Jose Enríque. Ariel. Montevideo: Colombino Hinos, 1947.

"Uma entrevista com Richard Morse". Estudos Históricos, Rio de Janeiro, vol. 2, n. 3, 1989.

SCHWARTZMAN, Simon. A redescoberta da cultura. São Paulo: EDUSP, 1997. 